(C) 2020, The Authors. Published by Elsevier Inc. and Fass Inc. on behalf of the American Dairy Science Association ${ }^{\circledR}$. This is an open access article under the CC BY-NC-ND license (http://creativecommons.org/licenses/by-nc-nd/4.0/).

\title{
Physical and economic comparison of pasture-based automatic and conventional milking systems
}

\author{
J. I. Gargiulo, ${ }^{1 *} \odot$ N. A. Lyons, ${ }^{2} \odot$ K. Kempton, ${ }^{2}$ D. A. Armstrong, ${ }^{3}$ and S. C. Garcia ${ }^{1} \odot$ \\ ${ }^{1}$ Dairy Science Group, School of Life and Environmental Sciences, Faculty of Science, The University of Sydney, Camden, NSW 2567, Australia \\ ${ }^{2}$ NSW Department of Primary Industries, Menangle, NSW 2568, Australia \\ ${ }^{3}$ D-ARM Consulting, Jindivick, VIC 3818, Australia
}

\begin{abstract}
Automatic milking systems (AMS) have the potential to increase dairy farm productivity and profitability; however, adoption rates, particularly in pasture-based systems, have been lower than expected. The objectives of this study were to compare the physical and economic performance of pasture-based AMS with conventional milking systems (CMS) and to identify gaps for improving AMS productivity and profitability. We used data from 14 AMS and 100 CMS located in the main Australian dairy regions and collected over 3 yr (2015-2016, 2016-2017, 2017-2018). Farms within similar regions and herd sizes were compared. Results showed that all the main physical performance indicators evaluated such as milk production per cow, milk production per hectare, pasture grazed per hectare, or milk solids per full-time equivalent were similar between systems. The AMS farms had higher overhead costs such as depreciation and repairs and maintenance; however, no differences in total labor costs were observed between systems. Profitability, measured as earnings before interest and tax, operating profit margin, and return on total assets, was not significantly different between AMS and CMS. Opportunities for improving pasture utilization, labor efficiency, and robot utilization in AMS farms were identified. Improving efficiency in these areas could improve productivity and profitability of these systems, and therefore increase the interest of this technology.
\end{abstract}

Key words: robotic milking, profitability, productivity, economics, business analysis

\section{INTRODUCTION}

Technological advancements allow dairy farmers to increase the efficiency of use of land, labor, and capital to produce milk, counteracting the long-term decline

Received February 5, 2020.

Accepted April 18, 2020.

*Corresponding author: juan.gargiulo@sydney.edu.au in the terms of trade (Ruttan, 2002; Kompas and Che, 2004; ABARES, 2019). Automatic milking systems (AMS) offer the possibility to increase productivity and profitability by potentially improving labor efficiency, milk production, animal welfare, and lifestyle (De Koning, 2002; Hogeveen et al., 2004; Mathijs, 2004; García and Fulkerson, 2005; Jacobs and Siegford, 2012; Wildridge et al., 2018). Adoption of AMS has grown significantly worldwide since the technology was first introduced in the Netherlands in 1992 (De Koning, 2010), with an estimated 50,000 units on 25,000 farms in operation in 2019 (T. Perrotin, DeLaval, Rochester, MN, personal communication). In some European countries, adoption reaches 23\% (Barkema et al., 2015) and it is estimated that half of the new dairy installations are AMS (O'Brien et al., 2015).

Research, development, and extension investment in pasture-based AMS was initiated in New Zealand in 2001 (Jago et al., 2002) and continued in Australia in 2004 with the national program FutureDairy (García et al., 2007). Despite the large number of success stories demonstrating the benefits of pasture-based AMS relating to labor and productivity, and that farmers perceive AMS to be within the 5 most adopted precision technologies by 2025 (Gargiulo et al., 2018), adoption remains below 1\% (N. A. Lyons, unpublished data). The reasons for the slower than expected adoption of pasture-based AMS are unclear but could be related to the lack of demonstration of the physical and economic performance of this technology in comparison with conventional milking systems (CMS; Bijl et al., 2007; Davies et al., 2010; Steeneveld et al., 2012; Salfer et al., 2017).

Most of the research comparing physical and economic performance of AMS and CMS has been conducted for confined housing systems using simulation models (Hyde and Engel, 2002; Rotz et al., 2003; Salfer et al., 2017). Three studies evaluated the profitability of pasture-based AMS (Jago et al., 2006; Davies et al., 2010; Shortall et al., 2016), however, these investigations were also based on modeling and some of the assumptions used (e.g., increased milk production or 
labor savings) might not be accurate. As far as we are aware, only 2 studies (Bijl et al., 2007; Steeneveld et al., 2012) have used commercial farm data; however, these were based on confined housing systems, which are not directly comparable to pasture-based dairy systems.

The objectives of the current study were therefore to compare the physical and economic performance of pasture-based AMS and CMS using data from commercial Australian dairy farms and to identify gaps for improving AMS productivity and profitability.

\section{MATERIALS AND METHODS}

\section{Data Collection}

A comprehensive whole-farm physical and economic data set collected over 3 financial years (2015-2016, 2016-2017, and 2017-2018) was used for this study. Data from CMS farms were available through the Dairy Farm Monitor Project (DFMP), a benchmarking program that monitors physical and economic performance indicators of close to 250 farms across all dairy regions in Australia ( $\sim 5 \%$ of the total dairy farms in the country, with more than $90 \%$ pasture-based systems; Dairy Australia, 2018, 2019). Data were collected by trained staff and validated by an expert panel of farm business consultants to ensure reliability and accuracy throughout the process. Farms participating in DFMP represent a distribution of farm and herd sizes and geographical locations within each Australian dairy region. This program uses a whole-farm business analysis methodology adapted from Malcolm et al. (2005) and is shown in Figure 1. Physical performance indicators were considered those that typically relate to production outputs, physical inputs, productivity, and production efficiency measures (e.g., total milk production, farm area, number of cows, milk per hectare, and labor efficiency). Economic performance indicators were those that relate to income, costs, and business profitability measures (e.g., gross farm income, variable and overhead costs, earnings before interest and tax, operating profit margin, and return on total assets). Income and costs were expressed in Australian dollars ( $\mathrm{A} \$$; average exchange rate for the period of the study: $\mathrm{A} \$ 1=\mathrm{US} \$ 0.79$ ) per kilogram of milk solids (MSD), where MSD is defined as kilograms of fat + kilograms of protein. Operating profit margin (\%) was calculated as earnings before interest and tax/gross farm income $\times 100$. Current prices were calculated by adjusting nominal prices to the year 2017-2018 by using the consumer price index (Australian Bureau of Statistics, 2019). Data from AMS farms were collected following the same methodology as DFMP. A total of 14 AMS farms ( $\sim 30 \%$ of the AMS population in Australia) located in New South Wales, South Australia, Tasmania, Victoria, and Western Australia provided their data over the same $3 \mathrm{yr}$. This represents the dairy regions where $96 \%$ of milk in Australia is produced. The final AMS data set included 9 farms in 2015-2016, 12 farms in 2016-2017, and 9 farms in 2017-2018. Half of the farms $(\mathrm{n}=7)$ participated in 2 out of $3 \mathrm{yr}$ of the study, while the others participated in either $3(\mathrm{n}=4)$ or $1 \mathrm{yr}$ $(\mathrm{n}=3)$. In addition, data from $203 \mathrm{CMS}$ farms $(\sim 3.6 \%$ of CMS Australian population) located in New South Wales, South Australia, Tasmania, and Victoria were used for this study. Data from CMS farms in Western Australia (which represents $<3 \%$ of the dairy farms in Australia) could not be used because some indicators, such as the number of milking cows or the milking area, were not available. The final CMS data set contained 153 farms in 2015-2016, 143 farms in 2016-2017, and 156 in 2017-2018. The majority of the CMS farms participated in $3 \mathrm{yr}$ of the study $(\mathrm{n}=98)$, whereas the rest participated in either $2(\mathrm{n}=53)$ or only $1 \mathrm{yr}(\mathrm{n}=52)$.

\section{Statistical Analyses}

Given the known effect of herd size on profitability (Hadley et al., 2002; Dairy Australia, 2013) and the smaller sample size of AMS farms, we applied a selection criterion based on herd size to enable a proper comparison between both systems. Each AMS farm was paired with all CMS farms within a similar region (i.e., "North" for farms located in New South Wales or Western Australia and "South" for farms located in Victoria, Tasmania, or South Australia) and with a similar average number of milking cows (i.e., CMS farms with $\pm 10 \%$ of the AMS farm). If a given CMS could be paired with more than one AMS, it was allocated to the group of the closest AMS in terms of the number of cows. This selection process resulted in 14 groups (i.e., as many groups as AMS farms) containing 1 AMS and between 2 and 22 CMS each (in total 14 AMS and 100 CMS farms). These 14 groups were used for the first comparison conducted and termed throughout this manuscript as "All Farms" (AF). In addition, a second comparison termed "Top 25\%" (T25) was also conducted. In this comparison, the 14 AMS and 100 CMS farms were ranked in descending order by the average earnings before interest and tax (EBIT) and only the top $25 \%$ farms within each system were selected. Therefore, this selection process resulted in 4 AMS and 25 CMS being used for this analysis.

A linear mixed model was used for the statistical analysis. The outcomes of interest related to different physical and economic parameters are shown in Figure 
1 , and the main explanatory variable was milking system (AMS or CMS). For the AF comparison, group, farm, and year were used as random effects. For the T25 farms comparison, farm and year were included as a random effect. Data preparation and statistical analysis were performed with $\mathrm{R}$ software, version 3.6.2 (www.r-project.org/). All variables were checked for assumptions of linearity, normality, and homoscedasticity. If the assumptions were invalid, variables were logtransformed. Parameter estimates were calculated using restricted maximum likelihood procedures. Significance was determined if $P<0.05$, and a trend toward significance was considered if $P>0.05$ and $P<0.10$.

\section{RESULTS}

\section{General Farm Information}

The 14 AMS farms milked between 130 and 360 cows, had between 40 and 151 ha of milking area, and 2 to 4 people (full-time equivalent; FTE) working on the farm. On average, the AMS farms had 4 robotic units (ranging from 2-7 units) and $4 \mathrm{yr}$ of experience operating these systems (ranging from 2-8 yr). The 100 CMS farms selected for the analysis milked between 132 and 395 cows, had between 9 and 250 ha of milking area, and between 3 and 5 people working on the farm.

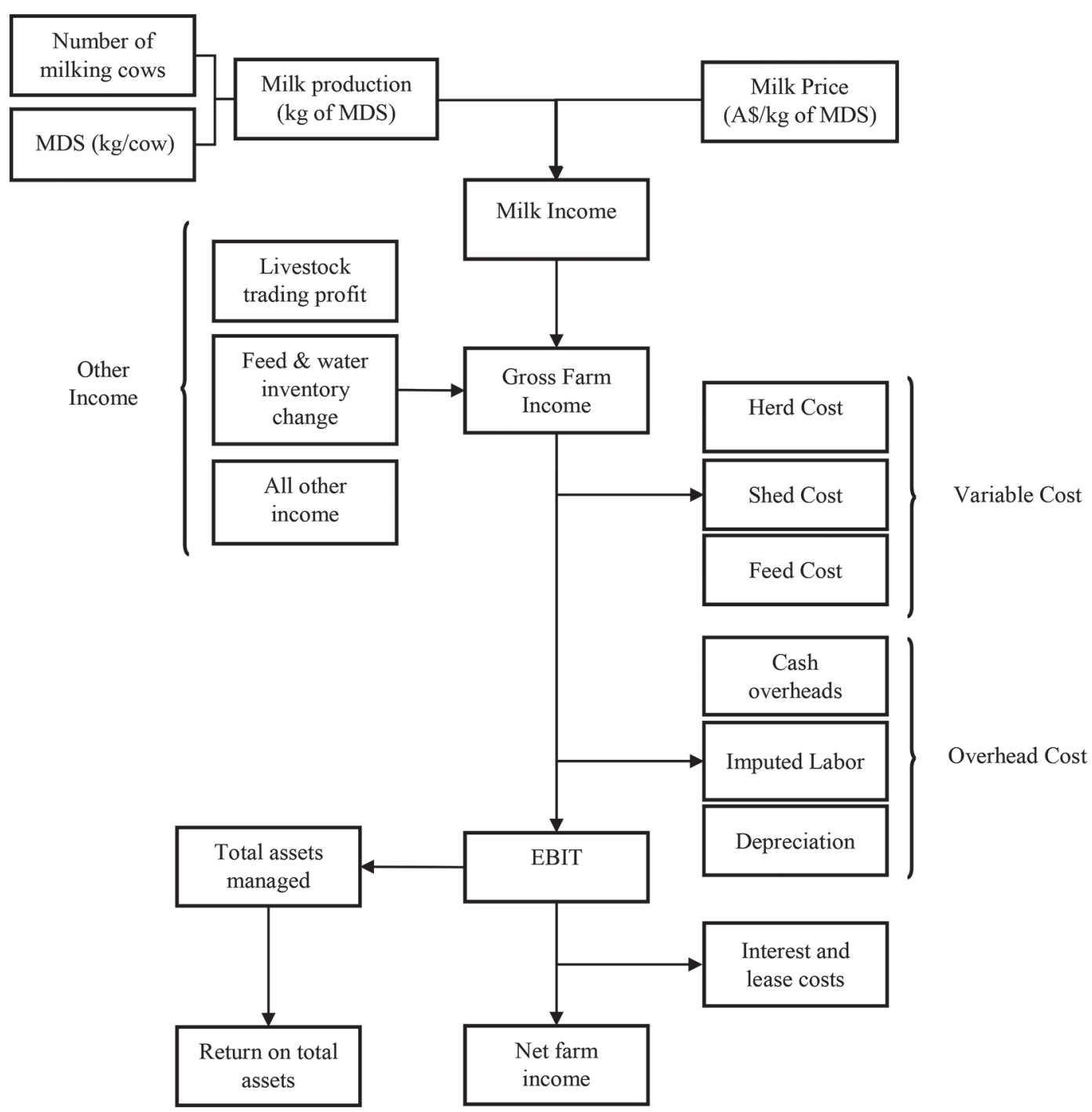

Figure 1. Business analysis methodology adapted from the Dairy Farm Monitor Project. MDS = milk solids; EBIT $=$ earnings before interest and tax. 
Table 1. Comparison of the main physical indicators (all farms)

\begin{tabular}{|c|c|c|c|c|}
\hline Item & \multicolumn{2}{|c|}{ Milking system ${ }^{1}$} & $\mathrm{SED}^{2}$ & $P$-value \\
\hline Log total usable area ${ }^{3}$ (ha) & 2.24 & 2.23 & 0.06 & 0.957 \\
\hline Milking area (ha) & 90 & 108 & 11 & 0.108 \\
\hline Number of milking cows & 222 & 224 & 11 & 0.593 \\
\hline Stocking rate (cows/usable area) & 1.36 & 1.55 & 0.20 & 0.362 \\
\hline Milk solids (kg/cow) & 466 & 497 & 22 & 0.178 \\
\hline Fat $(\%)$ & 4.02 & 4.20 & 0.10 & 0.090 \\
\hline Protein (\%) & 3.28 & 3.40 & 0.05 & 0.018 \\
\hline Pasture grazed ( $\mathrm{t}$ of $\mathrm{DM} / \mathrm{ha})$ & 6.2 & 6.5 & 0.7 & 0.724 \\
\hline Purchased feed per cow ( $t$ of $D M / c o w)$ & 2.2 & 2.4 & 0.3 & 0.354 \\
\hline Homegrown feed $(\%)$ & 66 & 61 & 4 & 0.118 \\
\hline Imputed labor $(\%)$ & 67 & 62 & 7 & 0.451 \\
\hline
\end{tabular}

\section{Physical and Economic Comparison-All Farms}

In general, most of the physical variables analyzed (total usable area, milk production, MSD/hectare, MSD/cow, and total labor used) were similar between AMS and CMS (Table 1). Only protein content (\%) was lower $(P=0.018)$ for AMS than CMS. Milk income per kilogram of MSD was 3.9\% higher for AMS $(P=0.047)$, however gross farm income was similar between systems (A $\$ 7.07 / \mathrm{kg}$ of MSD on average) $(P>$ $0.05)$. No difference in total variable costs was observed between systems $(P>0.05)$. However, AMS farms had approximately double the amount of total shed costs (shed power and dairy supplies) than CMS farms $(P$ $<0.001)$, a trend to lower total herd cost $(P=0.070)$, and no difference in total feed costs $(P>0.05)$. Alternatively, total overhead costs were $23 \%$ higher for AMS $(P=0.001)$, explained by a greater depreciation and repairs and maintenance $(P<0.05)$. Total labor costs, including employed and imputed labor costs (here defined as the allocated allowance for the cost of owner or operator, family, and sharefarmer time in the business), were similar for both systems $(P>0.05)$. Overall profitability measured as EBIT, operating profit margin, or return on total assets (ROTA) did not differ between systems $(P>0.05)$, with an average of $\mathrm{A} \$ 0.49 / \mathrm{kg}$ of MSD, $6.17 \%$, and $1.67 \%$, respectively (Table 2 ). Net farm income was negative and A $\$ 0.82 / \mathrm{kg}$ of MSD lower for AMS $(P=0.002)$, driven by almost double interest and lease costs for AMS farms $(P<0.001)$.

\section{Physical and Economic Comparison-Top 25\% Farms}

When comparing top-performing farms, most of the physical indicators such as MSD per hectare, MSD per cow, and MSD per FTE were similar between AMS and CMS $(P>0.05)$ (Table 3). However, the AMS farms milked 75 cows less on average than the CMS farms $(P$ $=0.014)$, had lower total labor (FTE) per farm $(P=$ $0.017)$, and a trend to lower milk production per farm $(P=0.055)$. For most of the economic performance indicators, no differences were observed between the T25 farms in either system (Table 4). Gross farm income and milk income were similar on average between systems (7.08 and $6.23 \mathrm{~A} \$ / \mathrm{kg}$ of MSD, respectively; $P$ $>0.05)$. Despite no difference in total variable costs between systems $(P>0.05)$, total shed costs (including shed power and dairy supplies) were about double for AMS farms $(P<0.001)$. The T25 AMS farms had higher depreciation $(P=0.044)$, but similar repairs and maintenance, total labor costs, and total overhead costs $(P>0.05)$. Profitability measured in EBIT and ROTA did not differ between T25 AMS and T25 CMS $(P>$ $0.05)$, with averages of $\mathrm{A} \$ 1.49 / \mathrm{kg}$ of $\mathrm{MSD}$ and $4.63 \%$ for each system, respectively. However, when profitability was measured as operating profit margin, T25 
Table 2. Comparison of the main economic indicators (in $\mathrm{A} \$ / \mathrm{kg}$ of milk solids; all farms; average exchange rate for the period of the study: $\mathrm{A} \$ 1=\mathrm{US} \$ 0.79)$

\begin{tabular}{|c|c|c|c|c|}
\hline \multirow[b]{2}{*}{ Item } & \multicolumn{2}{|c|}{ Milking system ${ }^{1}$} & \multirow[b]{2}{*}{$\mathrm{SED}^{2}$} & \multirow[b]{2}{*}{$P$-value } \\
\hline & AMS & CMS & & \\
\hline Gross farm income & 7.18 & 6.95 & 0.28 & 0.278 \\
\hline Milk income & 6.39 & 6.15 & 0.21 & 0.047 \\
\hline Total variable costs & 3.53 & 3.62 & 0.24 & 0.650 \\
\hline Total herd costs & 0.25 & 0.31 & 0.03 & 0.070 \\
\hline $\mathrm{AI}$ and herd test & 0.06 & 0.12 & 0.02 & 0.000 \\
\hline Animal health & 0.16 & 0.15 & 0.02 & 0.593 \\
\hline Calf rearing & 0.04 & 0.04 & 0.01 & 0.865 \\
\hline Total shed costs & 0.46 & 0.22 & 0.02 & $<0.001$ \\
\hline Shed power & 0.23 & 0.12 & 0.01 & $<0.001$ \\
\hline Dairy supplies & 0.23 & 0.11 & 0.02 & $<0.001$ \\
\hline Total feed costs & 2.81 & 3.07 & 0.22 & 0.159 \\
\hline Fertilizer & 0.38 & 0.38 & 0.05 & 0.985 \\
\hline Irrigation & 0.08 & 0.20 & 0.08 & 0.142 \\
\hline Hay and silage making & 0.17 & 0.18 & 0.04 & 0.872 \\
\hline Fuel and oil & 0.17 & 0.11 & 0.02 & 0.001 \\
\hline Pasture improvement and cropping & 0.11 & 0.20 & 0.03 & 0.005 \\
\hline Other feed costs & 0.02 & 0.06 & 0.02 & 0.074 \\
\hline Fodder, grain, and concentrates purchases & 1.85 & 1.89 & 0.18 & 0.769 \\
\hline Agistment costs & 0.02 & 0.10 & 0.04 & 0.038 \\
\hline Total overhead costs & 3.31 & 2.69 & 0.19 & 0.001 \\
\hline Cash overheads & 1.31 & 1.35 & 0.15 & 0.787 \\
\hline Registration and insurance & 0.12 & 0.12 & 0.02 & 0.556 \\
\hline Repairs and maintenance & 0.52 & 0.38 & 0.05 & 0.005 \\
\hline Other overheads & 0.24 & 0.23 & 0.03 & 0.627 \\
\hline Employed labor & 0.43 & 0.61 & 0.12 & 0.132 \\
\hline Imputed labor $^{3}$ & 1.18 & 1.03 & 0.13 & 0.262 \\
\hline Total labor costs & 1.58 & 1.61 & 0.12 & 0.751 \\
\hline Depreciation & 0.82 & 0.28 & 0.05 & $<0.001$ \\
\hline Interest and lease costs & 1.19 & 0.62 & 0.12 & 0.000 \\
\hline Earnings before interest and tax & 0.38 & 0.59 & 0.24 & 0.378 \\
\hline Operating profit margin (\%) & 4.44 & 7.94 & 3.67 & 0.324 \\
\hline Net farm income & -0.83 & 0.01 & 0.26 & 0.002 \\
\hline Return on total assets (\%) & 1.41 & 1.67 & 0.76 & 0.716 \\
\hline Cost of production ${ }^{4}$ & 6.82 & 6.35 & 0.32 & 0.069 \\
\hline
\end{tabular}

CMS had $6.27 \%$ more profit than T25 AMS farms ( $P$ $=0.042)$. Net farm income was almost zero for AMS and $\mathrm{A} \$ 1.09 / \mathrm{kg}$ of MSD for CMS $(P=0.001)$, a result associated with the more than double interest and lease costs for AMS farms $(P<0.001)$.

\section{DISCUSSION}

The aim of this study was to assess the current physical and economic situation of pasture-based AMS in comparison to CMS, and identify opportunities for improving productivity and profitability of AMS. Our results show that, for pasture-based farms with herd sizes between 130 and 395 cows, AMS and CMS farms can achieve relatively similar physical and economic performance.
Overall profitability, measured as EBIT, operating profit margin, and ROTA, were similar for AMS and CMS despite some differences in specific costs. However, the average profitability across systems was lower than the Australian average since 2006-2007 (EBIT, $\mathrm{A} \$ 1.32 / \mathrm{kg}$ of MSD; operating profit margin, $17 \%$; and ROTA, 4.38\%; Dairy Australia, 2018). This could be explained by a combination of lower farmgate milk prices and higher feed costs (driven by dry conditions in some regions), which also reduced the total milk produced (Dairy Australia, 2019). It is important to mention that despite the similarities of EBIT, operating profit margin, and ROTA across systems, net farm income was negative and significantly lower for AMS (Table 2), which was largely associated with increased interest and lease costs for AMS farms. 
Our commercial farm-based results contrast with previous modeling-based research for pasture-based and confined housing systems that showed that AMS was less profitable than CMS. In New Zealand, Jago et al. (2006) concluded that the profitability of an established AMS was lower than that of a CMS rotary system, mainly due to the higher interest, depreciation, and repairs and maintenance. In Ireland, Shortall et al. (2016) reported that CMS farms with a medium level of automation achieved higher profit than AMS at 2 different herd sizes (70 and 140 cows), whereas in the Netherlands, Bijl et al. (2007) showed that profitability was lower for AMS mainly due to larger overhead costs. On the contrary, Steeneveld et al. (2012), also in the Netherlands, concluded that both systems achieved similar profitability, and Salfer et al. (2017) showed that in the United States for herd sizes of 120 and 240 cows, AMS were more profitable. However, Salfer et al. (2017) also showed that at larger herd sizes (1,500 cows), CMS achieved better results mainly because they tend to run at full capacity for almost $24 \mathrm{~h} / \mathrm{d}$, reducing the required investment. The differences in research results between the current and previous studies is indicative of the number of factors influencing profitability, and how these vary between regions and feeding systems. Nevertheless, in comparison with previous research, our study is based on robust data systematically collected on commercial farms from different regions and a range of herd sizes.
Previous studies (Wagner-Storch and Palmer, 2003; Wade et al., 2004; De Koning, 2010), have suggested a potential of 2 to $10 \%$ increase in milk production on AMS farms mainly driven by an increase in milking frequency and better overall management, which is linked to improved animal comfort, health, and reproduction. Yet, in the current study, we found no difference in milk production between systems on either AF or T25 farms (Tables 1 and 3, respectively). However, previous research was mostly conducted in confinement housing where cows consumed a TMR and typically achieved higher DMI than in grazing conditions (Kolver and Muller, 1998). In addition, pasture-based AMS milking frequency is usually lower than AMS in confinement housing (Lyons et al., 2014), mainly due to longer walking distances. It is possible that the lack of difference in milk production for pasture-based AMS is explained by a combination of lower DMI and lower milking frequency, which is not much greater on average than that of CMS farms (Lyons and Kerrisk, 2017).

The main focus in pasture-based systems such as those in Australia is usually placed on optimizing pasture utilization to reduce variable costs, rather than only increasing individual cow production by achieving high DMI (Dairy Australia, 2013). The perceived adverse effects of AMS on pasture utilization was one of the initial concerns of the technology (van Dooren et al., 2004). Such perceptions had already been shown to be unfounded under controlled experiments (Dickeson,

Table 3. Comparison of the main physical indicators (top $25 \%$ of farms)

\begin{tabular}{|c|c|c|c|c|}
\hline \multirow[b]{2}{*}{ Item } & \multicolumn{2}{|c|}{ Milking system ${ }^{1}$} & \multirow[b]{2}{*}{$\mathrm{SED}^{2}$} & \multirow[b]{2}{*}{$P$-value } \\
\hline & AMS & CMS & & \\
\hline Total usable area $^{3}$ (ha) & 174 & 264 & 79 & 0.286 \\
\hline Milking area (ha) & 100 & 123 & 26 & 0.382 \\
\hline Number of milking cows & 209 & 284 & 28 & 0.014 \\
\hline Stocking rate (cows/usable area) & 1.53 & 1.54 & 0.49 & 0.977 \\
\hline Milk production $^{3}$ ( $\mathrm{kg}$ of milk solids/yr) & 108,232 & 146,819 & 18,727 & 0.055 \\
\hline Milk solids ( $\mathrm{kg} / \mathrm{ha})$ & 786 & 740 & 199 & 0.825 \\
\hline Milk solids (kg/cow) & 523 & 519 & 48 & 0.945 \\
\hline Fat $(\%)$ & 3.89 & 4.18 & 0.21 & 0.188 \\
\hline Protein (\%) & 3.31 & 3.39 & 0.09 & 0.405 \\
\hline Pasture grazed ( $\mathrm{t}$ of $\mathrm{DM} / \mathrm{ha})$ & 6.0 & 7.1 & 1.6 & 0.532 \\
\hline Purchased feed per cow ( $t$ of $D M / c o w)$ & 2.7 & 2.3 & 0.5 & 0.465 \\
\hline Homegrown feed $(\%)$ & 57 & 65 & 5 & 0.160 \\
\hline Cows/FTE ${ }^{4}$ & 120 & 104 & 18 & 0.379 \\
\hline Milk solids/FTE & 62,692 & 51,636 & 6,593 & 0.104 \\
\hline Total labor (FTE) & 1.8 & 2.9 & 0.4 & 0.017 \\
\hline Employed labor (FTE) & 0.7 & 1.6 & 0.5 & 0.109 \\
\hline Imputed labor (FTE) & 1.1 & 1.3 & 0.3 & 0.460 \\
\hline Imputed labor (\%) & 59 & 49 & 13 & 0.475 \\
\hline
\end{tabular}

${ }^{1} \mathrm{AMS}=$ automatic milking system; CMS = conventional milking system.

${ }^{2} \mathrm{SED}=$ average standard error of the difference.

${ }^{3}$ Total usable area and milk production were log-transformed, given that they did not meet the assumption of normality.

${ }^{4} \mathrm{FTE}=$ full-time equivalent $(2,400 \mathrm{~h} / \mathrm{yr}$, calculated as $48 \mathrm{~h} / \mathrm{wk}$ for $50 \mathrm{wk})$. 
2010; Clark et al., 2016) and were again confirmed in this study using commercial farm data. Yet, despite AMS and CMS farms achieving on average $6.2 \mathrm{t}$ of $\mathrm{DM} /$ ha of pasture grazed (ranging from 2.9-9.7 $\mathrm{t}$ of $\mathrm{DM} / \mathrm{ha}$ ), this is still much lower than the $13.5 \mathrm{t}$ of $\mathrm{DM} /$ ha reported by Clark et al. (2016) under experimental conditions, and the $\sim 22$ and $\sim 12 \mathrm{t}$ of $\mathrm{DM} /$ ha reported by the same research group under full (Fariña et al., 2011a) and partial irrigation (Fariña et al., 2011b) for a CMS research farm. Pasture harvested has been previously linked to farm profitability (Ramsbottom et al., 2015). In this data set, the bottom $25 \%$ farms (ranked by pasture grazed/ha) used only $3.3 \mathrm{t} / \mathrm{ha}$ of pasture and achieved A $\$ 0.32 / \mathrm{kg}$ of MSD of EBIT, whereas the T25 farms used $10.9 \mathrm{t} / \mathrm{ha}$ and achieved $\mathrm{A} \$ 1.24 / \mathrm{kg}$ of MSD of EBIT. Although profitability is multifactorial, this clearly shows the importance of optimizing pasture utilization on-farm.

The possibility of reducing labor requirements onfarm has also been mentioned by farmers as a major reason to invest in AMS (Hogeveen et al., 2004; Mathijs, 2004). This opportunity should be particularly attractive to Australian farmers, given that the country has the largest minimum wage within all the main dairy exporting countries (Australian Government, 2019; Eurostat, 2019; Gobierno Argentino, 2019; INE, 2019; NZ Government, 2019). However, our results showed that on average both systems had similar total labor use (employed, imputed, and total in FTE), labor efficiency (cows/FTE or MSD/FTE), and labor costs (total, imputed, and employed labor costs in $\mathrm{A} \$ / \mathrm{kg}$ of MSD). This contrasts with the study conducted in Europe by

Table 4. Comparison of the main economic indicators (in $\mathrm{A} \$ / \mathrm{kg}$ of milk solids; top $25 \%$ of farms; average exchange rate for the period of the study: $\mathrm{A} \$ 1=\mathrm{US} \$ 0.79$ )

\begin{tabular}{|c|c|c|c|c|}
\hline \multirow[b]{2}{*}{ Item } & \multicolumn{2}{|c|}{ Milking system ${ }^{1}$} & \multirow[b]{2}{*}{$\mathrm{SED}^{2}$} & \multirow[b]{2}{*}{$P$-value } \\
\hline & AMS & CMS & & \\
\hline Gross farm income & 7.07 & 7.09 & 0.57 & 0.977 \\
\hline Milk income & 6.37 & 6.09 & 0.42 & 0.513 \\
\hline Total variable costs & 3.53 & 3.13 & 0.33 & 0.243 \\
\hline Total herd costs & 0.25 & 0.29 & 0.05 & 0.462 \\
\hline $\mathrm{AI}$ and herd test & 0.07 & 0.11 & 0.03 & 0.141 \\
\hline Animal health & 0.13 & 0.13 & 0.03 & 0.929 \\
\hline Calf rearing & 0.05 & 0.05 & 0.03 & 0.991 \\
\hline Total shed costs & 0.43 & 0.20 & 0.04 & 0.000 \\
\hline Shed power & 0.20 & 0.11 & 0.01 & $<0.001$ \\
\hline Dairy supplies & 0.24 & 0.09 & 0.03 & 0.000 \\
\hline Total feed costs & 2.85 & 2.64 & 0.30 & 0.505 \\
\hline Fertilizer & 0.29 & 0.36 & 0.06 & 0.359 \\
\hline Irrigation & 0.06 & 0.08 & 0.05 & 0.781 \\
\hline Hay and silage making & 0.13 & 0.17 & 0.07 & 0.570 \\
\hline Fuel and oil & 0.10 & 0.10 & 0.03 & 0.976 \\
\hline Pasture improvement and cropping & 0.08 & 0.16 & 0.05 & 0.174 \\
\hline Log other feed costs & -1.40 & -1.18 & 0.01 & 0.596 \\
\hline Retransformed other feed costs & 0.04 & 0.07 & & \\
\hline Fodder, grain, and concentrates purchases & 2.13 & 1.59 & 0.27 & 0.064 \\
\hline Agistment costs & 0.02 & 0.11 & 0.07 & 0.293 \\
\hline Total overhead costs & 2.24 & 2.25 & 0.32 & 0.970 \\
\hline Cash overheads & 1.06 & 1.28 & 0.25 & 0.395 \\
\hline Registration and insurance & 0.10 & 0.10 & 0.03 & 0.968 \\
\hline Repairs and maintenance & 0.36 & 0.31 & 0.07 & 0.471 \\
\hline Other overheads & 0.16 & 0.19 & 0.04 & 0.525 \\
\hline Employed labor & 0.43 & 0.68 & 0.19 & 0.223 \\
\hline Imputed labor ${ }^{3}$ & 0.74 & 0.70 & 0.21 & 0.845 \\
\hline Total labor costs & 1.15 & 1.36 & 0.17 & 0.241 \\
\hline Depreciation & 0.45 & 0.27 & 0.09 & 0.044 \\
\hline Interest and lease costs & 1.33 & 0.60 & 0.18 & 0.000 \\
\hline Earnings before interest and tax & 1.28 & 1.70 & 0.22 & 0.073 \\
\hline Operating profit margin (\%) & 17.96 & 24.23 & 4.22 & 0.042 \\
\hline Net farm income & -0.03 & 1.09 & 0.29 & 0.001 \\
\hline Return on total assets (\%) & 4.09 & 5.18 & 0.77 & 0.180 \\
\hline Cost of production ${ }^{4}$ & 5.77 & 5.39 & 0.53 & 0.484 \\
\hline
\end{tabular}

${ }^{1} \mathrm{AMS}=$ automatic milking system; CMS $=$ conventional milking system.

${ }^{2} \mathrm{SED}=$ average standard error of the difference.

${ }^{3}$ Imputed owner or operator and family labor.

${ }^{4}$ Total variable costs plus total overhead costs. 
Bijl et al. (2007), who reported that AMS had $22 \%$ lower total FTE (mainly given by lower owner labor) and 28 and $25 \%$ higher labor efficiency (measured in milk/FTE and cows/FTE, respectively). However, our results are in line with Steeneveld et al. (2012), who reported no differences between AMS and CMS in total FTE, cows/FTE, milk/FTE, and labor costs (€/100 $\mathrm{kg}$ of milk). Steeneveld et al. (2012) hypothesized that the AMS farms could have been planning to expand the herd instead of reducing labor, or that in reality, net labor savings could not be as large as expected in AMS (some tasks disappear, but new tasks appear once the robots are installed). Anecdotal evidence from a survey by the authors of the current study of 19 farmers from Australia, Ireland, and New Zealand indicated that they primarily invested in this technology to acquire more flexibility in time management, to reduce the physical effects on the body from repetitive manual tasks, and because of labor availability. Only a minor proportion mentioned that they adopted AMS to reduce total labor costs (J. Gargiulo, unpublished data).

A large variability in total labor, labor efficiency, and labor costs between AMS farms was found in the present study. The farm with the lowest labor efficiency (ranked by MSD/FTE) produced 19,000 kg of MSD/ FTE, managed 55 cows/FTE, and spent the equivalent of $56 \%$ of the milk income in total labor costs. In contrast, the farm with the highest labor efficiency produced 97,792 kg of MSD/FTE, managed 181 cows/ FTE, and spent $15 \%$ of the income in total labor costs. Previous studies conducted in the United States on 33 AMS farms in confinement housing reported an average of 90 cows/FTE with a standard deviation of 34 cows/FTE (Siewert et al., 2018). A study in Australia conducted by Molfino et al. (2014), in which 5 pasturebased AMS were monitored monthly for a whole year, showed that AMS farms managed on average 181 cows/ FTE (ranging from 100-273 cows/FTE). This represents a $54 \%$ increase in labor efficiency in comparison to the average AMS in our study. Combined, these findings indicate that greater labor efficiency can be achievable on some AMS farms, and that this could have a potential effect on farm profitability.

Overhead costs (such as repairs and maintenance and depreciation), as well as interest and lease costs, were higher for AMS farms and accounted for the second largest costs after feed. These findings are similar to those reported in previous research (Steeneveld et al., 2012; Shortall et al., 2016; Salfer et al., 2017). The fact that an AMS operates constantly without direct human intervention, and that many of the major components are electronics and moving parts, might explain the need for more frequent repairs and maintenance. Additionally, most AMS farms have to commit to scheduled preventive services as a warranty requirement from the robot manufacturer (Lely, 2019). It is possible that not all CMS farms do regular maintenance, and therefore have a lower cost in comparison to AMS. In addition, some of the robot components, such as cameras, lasers, or arms, could be more expensive than the average equipment on a conventional dairy. The higher depreciation for AMS was expected given the higher initial capital investment of the technology. In this study, depreciation was calculated by applying a fixed rate of $10 \%$ to the market value of all owned plant and equipment assets on the farm (Dairy Australia, 2016), and a $7.14 \%$ rate for the AMS equipment. Interest and lease costs were higher for AMS, presumably due to higher interest paid for borrowed funds associated with the robot equipment. It is also worth mentioning that, in general, most of the finance for the robotic units is on relatively short-term equipment loans that require principal to be repaid in a short period. Alternatives such as secondhand robots or robot leasing plans are available in the market and might represent an option to reduce these initial costs.

Given the abovementioned factors, optimizing how efficiently the capital invested is used should have a significant effect on profitability. One key performance indicator usually suggested for measuring this is the robot utilization, or kilograms of milk harvested per robot per day (Castro et al., 2012; Tremblay et al., 2016; Salfer et al., 2017). In the current study, the average robot utilization per farm was $1,073 \mathrm{~kg} /$ robot per day, ranging between 597 and $1,367 \mathrm{~kg} /$ robot per day (data not shown). The T25 farms achieved on average $1,222 \mathrm{~kg} /$ robot per day, which is $14 \%$ higher than the average for AF. This variability might be explained by factors such as the number of cows managed per robot, the milking frequency per cow, and the milk production per cow. Previous studies on Australian pasture-based AMS report an average of $1,263 \mathrm{~kg} /$ robot per day and speculate that there is a potential to achieve at least $1,955 \mathrm{~kg} /$ robot per day (Lyons and Kerrisk, 2017). Data from 635 North American AMS farms in confinement housing collected over $4 \mathrm{yr}$ averaged $1,626 \mathrm{~kg} /$ robot per day and had a standard deviation of 397 (Tremblay et al., 2016). Castro et al. (2012), using information from 34 Spanish AMS farms, reported an average of $1,506 \mathrm{~kg} /$ robot per day with a maximum of 2,182 and a minimum of $650 \mathrm{~kg} /$ robot per day. It is clear that despite the higher milk harvested per robot in AMS in confinement housing, there is also room for improving robot utilization within pasture-based AMS. If we assume an average milk price of $\mathrm{A} \$ 0.46 / \mathrm{L}$, a value of $\mathrm{A} \$ 690,000$ for 4 AMS (plant and equipment), $7.14 \%$ of the AMS price for depreciation, $6 \%$ for interest, and $6 \%$ for repairs and maintenance, the most inefficient farm 
in our study produces an average of $597 \mathrm{~kg} /$ robot per day and spends $33 \%$ of the milk income on depreciation, interest, and repairs and maintenance. On the other hand, the most efficient farm produces $1,367 \mathrm{~kg} /$ robot per day and spends only $14 \%$ on these costs. Changes in variables such as milk price, AMS value, lifespan, and interest rates have an effect on profitability, but are in general out of the farmer's influence. However, robot utilization is a factor that the farmer can control, and the current gap in efficiency could be addressed to increase profitability.

\section{CONCLUSIONS}

This study provides a robust analysis of the current level of profitability of pasture-based AMS, taking into consideration differences in herd sizes and regions. The study also identifies key differences with CMS, which are important for farmers who are assessing investment in this technology. Our results showed that despite relatively minor differences in performance and farm economics, pasture-based AMS farms can achieve similar levels of productivity and profitability than pasturebased CMS farms. Opportunities for improving pasture utilization, labor efficiency, and robot utilization on AMS farms have been identified. Improving efficiency in these areas could have a significant effect on the profitability of these systems, making them more attractive and therefore potentially increasing uptake of the technology.

\section{ACKNOWLEDGMENTS}

The authors thank the farmers and the data collectors involved in this study. This research was part of Milking Edge (Narellan, Australia), an Australian dairy industry project funded by Dairy Australia (Southbank, Australia), the NSW Department of Primary Industries (Orange, Australia), and DeLaval (Tumba, Sweden), supporting AMS adoption. The first author is the recipient of a Postgraduate Research Scholarship in Automation and Robotics for Dairy Production supported by the NSW Department of Primary Industries and the Dairy Research Foundation. The authors have not stated any conflicts of interest.

\section{REFERENCES}

ABARES. 2019. Agricultural Productivity Estimates. Accessed Jun. 11, 2019. http://www.agriculture.gov.au/abares/research-topics/ productivity/agricultural-productivity-estimates\#dairy.

Australian Bureau of Statistics. 2019. Consumer Price Index. Accessed Oct. 3, 2019. https://www.abs.gov.au/ausstats/abs@.nsf/mf/6401 .0 .
Australian Government. 2019. National Minimum Wage in Australia. Accessed Jun. 11, 2019. https://www.business.gov.au/people/ hiring/pay-and-conditions/paying-your-employees.

Barkema, H. W., M. A. G. von Keyserlingk, J. P. Kastelic, T. J. G. M. Lam, C. Luby, J. P. Roy, S. J. LeBlanc, G. P. Keefe, and D. F. Kelton. 2015. Invited review: Changes in the dairy industry affecting dairy cattle health and welfare. J. Dairy Sci. 98:7426-7445. https://doi.org/10.3168/jds.2015-9377.

Bijl, R., S. R. Kooistra, and H. Hogeveen. 2007. The profitability of automatic milking on Dutch dairy farms. J. Dairy Sci. 90:239-248. https://doi.org/10.3168/jds.S0022-0302(07)72625-5.

Castro, A., J. M. Pereira, C. Amiama, and J. Bueno. 2012. Estimating efficiency in automatic milking systems. J. Dairy Sci. 95:929-936. https://doi.org/10.3168/jds.2010-3912.

Clark, C. E. F., S. R. Farina, S. C. Garcia, M. R. Islam, K. L. Kerrisk, and W. J. Fulkerson. 2016. A comparison of conventional and automatic milking system pasture utilization and pre- and postgrazing pasture mass. Grass Forage Sci. 71:153-159. https://doi .org/10.1111/gfs.12171.

Dairy Australia. 2013. Victorian Dairy Industry Milk Supply Trends: Analysis of the drivers of Farm Profit. Accessed Oct. 8, 2019. https: //www.dairyaustralia.com.au/farm/farm-business-management/ profitability-economics-and-research/dairy-milk-supply-trends.

Dairy Australia. 2016. Dairy Farm Business Analysis. Accessed Oct. 8, 2019. https://www.dairyaustralia.com.au/-/media/dairyaustralia/ documents/farm/farm-business-management/dairy-farm-business -sheets/dairy-farm-business-analysis-fact-sheets.ashx.

Dairy Australia. 2018. Dairy Farm Monitor Project. Accessed Sep. 2, 2019. https://www.dairyaustralia.com.au/farm/farm-business -management/dairy-farm-monitor-project.

Dairy Australia. 2019. Dairy Situation and Outlook: June 2019. Accessed Oct. 10, 2019. https://www.dairyaustralia.com.au/-/media/ situation-and-outlook-june-2019.pdf.

Davies, L., A. Alford, K. Kerrisk, and S. C. Garcia. 2010. Economics of Automatic Milking Systems. Future Dairy, University of Sydney, Australia.

De Koning, K. 2002. Automatic milking experience and development in Europe. Pages I1-I11 in Proc. First North Am. Conf. on Robotic Milking. Canada.

De Koning, K. 2010. Automatic milking - Common practice on dairy farms. Pages V59-V63 in Proc. Second North Am. Conf. on Robotic Milking. Toronto, Canada. Precision Dairy Operators, Elora, Canada.

Dickeson, D. 2010. Page 111 in Quantification of the Effects of Inaccurate Pasture Allocation in a Pasture Based Automatic Milking System. The University of Sydney, Australia.

Eurostat. 2019. Minimum Wage Statistics. Accessed Jul. 20, 2019. https://ec.europa.eu/eurostat/statistics-explained/index.php/ Minimum_wage_statistics.

Fariña, S. R., S. C. Garcia, and W. J. Fulkerson. 2011a. A complementary forage system whole-farm study: Forage utilisation and milk production. Anim. Prod. Sci. 51:460-470. https://doi.org/10 .1071/AN10242.

Fariña, S. R., S. C. Garcia, W. J. Fulkerson, and I. M. Barchia. 2011b. Pasture-based dairy farm systems increasing milk production through stocking rate or milk yield per cow: Pasture and animal responses. Grass Forage Sci. 66:316-332. https://doi.org/10.1111/ j.1365-2494.2011.00795.x.

García, S. C., and W. Fulkerson. 2005. Opportunities for future Australian dairy systems: A review. Aust. J. Exp. Agric. 45:1041-1055. https://doi.org/10.1071/EA04143.

García, S. C., W. J. Fulkerson, R. Nettle, S. Kenny, and D. Armstrong. 2007. FutureDairy: A national, multidisciplinary project to assist dairy farmers to manage future challenges methods and early findings. Aust. J. Exp. Agric. 47:1025-1031. https://doi.org/10.1071/ EA06064.

Gargiulo, J. I., C. R. Eastwood, S. C. García, and N. A. Lyons. 2018. Dairy farmers with larger herd sizes adopt more precision dairy technologies. J. Dairy Sci. 101:5466-5473. https://doi.org/10 $.3168 /$ jds.2017-13324. 
Gobierno Argentino. 2019. Ministerio de Producción y Trabajo: Resoluciones del Salario Mínimo, Vital y Móvil. Accessed Jun. 11, 2019. https://www.boletinoficial.gob.ar/detalleAviso/primera/213533/ 20190815.

Government, NZ. 2019. Minimum wage. Accessed Jun. 11, 2019. https: //www.govt.nz/browse/work/workers-rights/minimum-wage/.

Hadley, G. L., S. B. Harsh, and C. A. Wolf. 2002. Managerial and financial implications of major dairy farm expansions in Michigan and Wisconsin. J. Dairy Sci. 85:2053-2064. https://doi.org/10 .3168/jds.S0022-0302(02)74283-5.

Hogeveen, H., K. Heemskerk, and E. Mathijs. 2004. Motivations of Dutch farmers to invest in an automatic milking system or a conventional milking parlour. Pages 56-61 in Automatic Milking: A Better Understanding. A. Meijering, H. Hogveen, and C. J. A. M. de Koning, ed. Wageningen Academic Publishers, Wageningen, the Netherlands.

Hyde, J., and P. Engel. 2002. Investing in a robotic milking system: A Monte Carlo simulation analysis. J. Dairy Sci. 85:2207-2214. https://doi.org/10.3168/jds.S0022-0302(02)74300-2.

INE. 2019. Salario Mínimo Nacional. Accessed Jun. 11, 2019. http:// www.ine.gub.uy/salario-minimo-nacional.

Jacobs, J. A., and J. M. Siegford. 2012. Invited review: The impact of automatic milking systems on dairy cow management, behavior, health, and welfare. J. Dairy Sci. 95:2227-2247. https://doi.org/ 10.3168/jds.2011-4943.

Jago, J., P. Copeman, K. Bright, D. McLean, I. Ohnstad, and M. Woolford. 2002. An innovative farm system combining automated milking with grazing. Pages 115-119 in Proc. of the New Zealand Soc. of Anim. Prod. Vol. 62. New Zealand Society of Animal Production, Palmerston North.

Jago, J. G., K. L. Davis, M. Newman, and M. W. Woolford. 2006. An economic evaluation of automatic milking systems for New Zealand dairy farms. Proc. N.Z. Soc. Anim. Prod. 66:263-269.

Kolver, E. S., and L. Muller. 1998. Performance and nutrient intake of high producing Holstein cows consuming pasture or a total mixed ration. J. Dairy Sci. 81:1403-1411. https://doi.org/10.3168/jds .S0022-0302(98)75704-2.

Kompas, T., and T. N. Che. 2004. Productivity in the Australian dairy industry. Australasian Agribusiness Review 12:2. https://doi.org/ 10.22004/ag.econ.132077.

Lely. 2019. Lely General Terms and Conditions of Sale. Accessed Aug. 10, 2019. https://www.lely.com/au/legal-notice/sales-terms/.

Lyons, N. A., and K. L. Kerrisk. 2017. Current and potential system performance on commercial automatic milking farms. Anim. Prod. Sci. 57:1550-1556. https://doi.org/10.1071/AN16513.

Lyons, N. A., K. L. Kerrisk, and S. C. Garcia. 2014. Milking frequency management in pasture-based automatic milking systems: A review. Livest. Sci. 159:102-116. https://doi.org/10.1016/j.livsci .2013.11.011.

Malcolm, B., J. Makeham, and V. Wright. 2005. The Farming Game: Agricultural Management and Marketing. Cambridge University Press, Cambridge, UK.

Mathijs, E. 2004. Socio-economics aspects of automatic milking. Pages 46-55 in Automatic Milking: A Better Understanding. A. Meijering, H. Hogveen, and C. J. A. M. de Koning, ed. Wageningen Academic Publishers, Wageningen, the Netherlands.

Molfino, J., K. Kerrisk, and S. García. 2014. Investigation into the labour and lifestyle impacts of automatic milking systems (AMS) on commercial farms in Australia. Pages 339-342 in Proc. Proc. fifth Australian Dairy Sci. Symp., Melbourne, Australia. Australasian Dairy Science Symposium Committee, Hamilton, New Zealand.

O'Brien, B., C. Foley, J. Shortall, and L. Shalloo. 2015. An economic appraisal of automatic and conventional milking within a grass based seasonal milk production system. Pages 21-29 in Proc. Precision Livestock Farming 2015-Papers Presented at the 7th European Conference on Precision Livestock Farming, ECPLF, Milan, Italy. European Association for Precision Livestock Farming, Parma, Italy.

Ramsbottom, G., B. Horan, D. P. Berry, and J. R. Roche. 2015. Factors associated with the financial performance of spring-calving, pasture-based dairy farms. J. Dairy Sci. 98:3526-3540. https://doi .org/10.3168/jds.2014-8516.

Rotz, C. A., C. U. Coiner, and K. J. Soder. 2003. Automatic milking systems, farm size, and milk production. J. Dairy Sci. 86:41674177. https://doi.org/10.3168/jds.S0022-0302(03)74032-6.

Ruttan, V. W. 2002. Productivity growth in world agriculture: Sources and constraints. J. Econ. Perspect. 16:161-184. https://doi.org/10 $.1257 / 089533002320951028$.

Salfer, J. A., K. Minegishi, W. Lazarus, E. Berning, and M. I. Endres. 2017. Finances and returns for robotic dairies. J. Dairy Sci. 100:7739-7749. https://doi.org/10.3168/jds.2016-11976.

Shortall, J., L. Shalloo, C. Foley, R. D. Sleator, and B. O'Brien. 2016. Investment appraisal of automatic milking and conventional milking technologies in a pasture-based dairy system. J. Dairy Sci. 99:7700-7713. https://doi.org/10.3168/jds.2016-11256.

Siewert, J. M., J. A. Salfer, and M. I. Endres. 2018. Factors associated with productivity on automatic milking system dairy farms in the Upper Midwest United States. J. Dairy Sci. 101:8327-8334. https: //doi.org/10.3168/jds.2017-14297.

Steeneveld, W., L. W. Tauer, H. Hogeveen, and A. G. J. M. Oude Lansink. 2012. Comparing technical efficiency of farms with an automatic milking system and a conventional milking system. J. Dairy Sci. 95:7391-7398. https://doi.org/10.3168/jds.2012-5482.

Tremblay, M., J. P. Hess, B. M. Christenson, K. K. McIntyre, B. Smink, A. J. van der Kamp, L. G. de Jong, and D. Döpfer. 2016. Factors associated with increased milk production for automatic milking systems. J. Dairy Sci. 99:3824-3837. https://doi.org/10 $.3168 /$ jds.2015-10152.

van Dooren, H., L. Heutinck, and G. Biewenga. 2004. Combining automatic milking and grazing. Practice in the Netherlands/ Page 305 in Automatic Milking: A Better Understanding. A. Meijering, $\mathrm{H}$. Hogveen, and C. J. A. M. de Koning, ed. Wageningen Academic Publishers, Wageningen, the Netherlands.

Wade, K. M., M. Asseldonk, P. B. M. Berentsen, W. Ouweltjes, and H. Hogeveen. 2004. Economic efficiency of automatic milking systems with specific emphasis on increases in milk production. Pages 62-67 in Automatic Milking: A Better Understanding. A. Meijering, H. Hogeveen, and C. J. A. M. de Koning, ed. Wageningen Academic Publishers, Wageningen, the Netherlands.

Wagner-Storch, A. M., and R. W. Palmer. 2003. Feeding behavior, milking behavior, and milk yields of cows milked in a parlor versus an automatic milking system. J. Dairy Sci. 86:1494-1502. https:// doi.org/10.3168/jds.S0022-0302(03)73735-7.

Wildridge, A. M., P. C. Thomson, S. C. Garcia, E. C. Jongman, C. E. Clark, and K. L. Kerrisk. 2018. The impact of fetching at night on milking parlour visitation for pasture-based dairy cattle. Appl. Anim. Behav. Sci. 201:25-30. https://doi.org/10.1016/j.applanim .2017.12.014.

\section{ORCIDS}

J. I. Gargiulo @ https://orcid.org/0000-0002-2418-0398

N. A. Lyons @ https://orcid.org/0000-0002-7137-4937

S. C. Garcia @ https://orcid.org/0000-0002-2742-0262 